\title{
Pengembangan dan Implementasi Program Aplikasi Koreksi Ejaan untuk Membantu Guru Memeriksa Naskah Soal
}

\author{
Viny Christanti M. ${ }^{1}$, Zyad Rusdi², Bagus Mulyawan ${ }^{3}$ \\ 1,2,3 Fakultas Teknologi Informasi, Universitas Tarumanagara
}

viny@untar.ac.id, zyadr@fti.untar.ac.id, bagus@untar.ac.id

\begin{abstract}
Abstrak
Setiap guru wajib untuk memberikan soal secara rutin baik untuk latihan sehari-hari, penilaian harian, tengah semester atau akhir semester. Saat ini soal disiapkan secara elektronik dan secara tidak sadar kesalahan pengetikan dapat terjadi seperti kesalahan kurang huruf, kelebihan huruf atau huruf yang tertukar. Kepala sekolah dan guru selalu memeriksa kembali setiap naskah soal yang akan diberikan kepada siswa. Saat ini aplikasi word processing sudah memiliki auto spelling correction yang dapat digunakan untuk membantu memberikan koreksi pada ejaan yang salah. Namun biasanya tersedia untuk Bahasa Inggris dan langsung memeriksa setiap kata yang diketik dan mengkoreksi kata tersebut. Sekolah membutuhkan aplikasi yang dapat memeriksa dan memberikan koreksi setelah naskah selesai dibuat. Tujuan program PKM ini adalah untuk meningkatkan ketrampilan guru dalam menggunakan teknologi untuk memudahkan pekerjaan guru dalam mengevaluasi naskah soal ujian. Metode yang digunakan dalam PKM ini adalah metode pengembangan program komputer System Development Life Cycle. PKM ini dilaksanakan dari Januari-Oktober 2019. Sasaran PKM ini adalah guru SD. Tiara Kasih adalah salah satu sekolah yang cukup ketat dalam proses memeriksa soal. bentuk program dari PKM ini adalah membuat program aplikasi SKEBI Dokumen Soal Ujian dengan menerapkan IPTEK hasil penelitian yang sudah dilakukan oleh tim peneliti PKM.
\end{abstract}

Kata Kunci: Koreksi Ejaan, Naskah Soal Ujian, SD Tiara Kasih, SKEBI Dokumen

\section{PENDAHULUAN}

Mengetik merupakan salah satu kegiatan sehari-hari yang umum dilakukan saat ini. Pengetikan dapat dilakukan dengan menggunakan beberapa aplikasi di komputer seperti Microsoft Office, Open Office dan lainnya. Dalam mengetik sering kali dapat terjadi kesalahan. Kesalahan yang dapat terjadi dalam pengetikan adalah kurang huruf, kelebihan huruf atau huruf yang terbalik. Kesalahan dalam pengetikan biasanya disebabkan oleh kurang teliti dalam menekan tombol atau terlalu cepat mengetik.
Secara umum, sistem koreksi ejaan dapat diimplementasikan dalam bentuk aplikasi berdiri sendiri (stand-alone application), bagian dari aplikasi besar lainnya seperti word processing, search engine dan lainnya. Secara umum, alat bantuan koreksi ejaan akanmemeriksa kata pada saat pengguna mengetikan sebuah kata. Beberapa sistem koreksi yang berdiri sendiri juga dapat digunakan untuk memeriksa, memberi tanda atau langsung merubah kata pada satu file dokumen. Sehingga koreksi diberikan secara otomatis ketika dokumen selesai diketikan.

Dalam membangun aplikasi tersebut, tim telah melakukan penelitian selama 2 tahun mulai

Teknologi Informasi dan Komunikasi 
tahun 2017. Pada tahun 2018, peneliti mencoba mematangkan penelitian ini sehingga hasil penelitian ini dapat berguna bagi masyakarat. Oleh karena itu peneliti membentuk tim PKM yang dibentuk untuk mengembangkan dan mengimplementasikan hasil penelitian kepada masyarakat.

Hasil penelitian terdahulu sudah menghasilkan penelitian yang saat ini ingin diterapkan ke dalam masyarakat. Dalam menerapkan aplikasi tersebut, dibutuhkan beberapa penyesuaian agar produk yang dihasilkan dari penelitian dapat disesuaikan dengan kebutuhan masing-masing pengguna. SD Tiara Kasih menjadi salah satu sekolah yang menjadi mitra kerja sama. Tim berusaha menerapkan dan menyesuaikan aplikasi ini sesuai dengan kebutuhan sekolah yang menjadi mitra.

Sekolah memiliki tugas untuk memberikan pendidikan yang terbaik untuk siswanya. Guru adalah salah satu bagian dari sekolah yang memiliki peran dalam proses pengajaran. Salah satu tugas guru adalah melakukan penilaian terhadap hasil belajar siswa (Sani, 2013). Proses penilaian dapat dilakukan melalui pemberian tes dalam bentuk soal. Guru memiliki tugas untuk membuat soal untuk menilai kemampuan siswa. Soal dapat diberikan untuk latihan, penilaian harian, ulangan tengah semester atau ulangan kenaikan kelas.

Proses pembuatan soal biasa dilakukan dengan mengetik soal menggunakan bantuan komputer. Setelah soal selesai dibuat, pemeriksaan ulang soal perlu dilakukan untuk mengevaluasi kembali materi dan penulisan soal. Hasil pengetikan soal terkadang masih memiliki kesalahan seperti kesalahan pengetikan yang tidak sengaja terjadi. Beberapa kesalahan yang umum terjadi adalah kekurangan huruf, kelebihan huruf atau huruf yang tidak sengaja tertukar pada saat mengetik soal.

Tiara Kasih adalah salah satu sekolah yang sudah berdiri selama 20 tahun. Sekolah Tiara Kasih memiliki visi menjadi lembaga pendidikan yang berkualitas tinggi dalam proses pendidikan dan pengajaran (Tiara Kasih, 2018). Sekolah Tiara Kasih merupakan salah satu sekolah terbaik yang berlokasi di Jakarta Barat.

Sekolah Tiara Kasih sudah memiliki website aplikasi berbasis android dalam menyampaikan materi kepada orang tua dan siswa.
Dimana orang tua dan siswa dapat melihat agenda, nilai dan informasi lainnya melalui aplikasi tersebut. Dalam mendukung kegiatan belajar mengajar sehari-hari, sekolah ini sudah menggunakan komputer untuk membuat berbagai kebutuhan administrasi dan surat menyurat termasuk membuat soal untuk siswa. Pengolahan dan pembuatan dokumen secara elektronik sudah digunakan. Untuk meningkatkan kualitas naskah dokumen yang dibuat maka setiap naskah yang dibuat harus dipastikan bebas dari kesalahan pengetikan.

Salah satu cara memberikan pengajaran yang baik adalah memberikan latihan secara periodik kepada siswa untuk menilai kemampuan siswa. Berdasarkan hasil wawancara dengan kepala sekolah Tiara Kasih, penulisan naskah soal yang akan diberikan ke siswa selalu diperiksa ulang agar naskah soal yang diberikan terhindar dari kesalahan pengetikan.

Setelah guru kelas mengetik soal, kepala sekolah akan membaca kembali soal-soal yang sudah diketik. Pemeriksaan ulang dilakukan untuk menjaga kualitas soal yang akan diberikan kepada siswa. Hasil pemeriksaan ulang lebih banyak menemukan kesalahan dalam kesalahaan pengetikan ejaan. Kesalahan yang umum ditemukan adalah kelebihan huruf seperti "saya" menjadi "sayaa", kekurangan huruf seperti "makan" menjadi "mkan" atau huruf yang tertukar seperti "bisa" menjadi "bias".

Namun banyaknya jumlah soal yang dibuat dari kelas 1-6 SD, membuat proses pemeriksaan ulang sulit dilakukan dan kurang maksimal. Sehingga masih saja ditemukan beberapa kesalahan pengetikan pada soal yang diberikan ke siswa.

Spelling correction adalah proses untuk memperbaiki ejaan agar sesuai dengan kata yang seharusnya (Pirinen, T., 2014). Proses spelling correction dilakukan dengan menggunakan spell checker. Spell checker adalah aplikasi program yang digunakan untuk memberi tanda kata-kata yang memiliki ejaan yang kurang tepat. Spell checker dapat berupa program sendiri atau menjadi satu dengan aplikasi pengolahan kata.

Aplikasi spell checker akan memeriksa lalu merubah secara otomatis. Pemeriksaan kata dapat dibangun dengan membandingkan data yang ada di

Teknologi Informasi dan Komunikasi 
kamus atau menggunakan berbagai metode untuk memprediksi kata yang seharusnya benar.

Alat bantu koreksi ejaan sudah banyak tersedia di berbagai aplikasi. Saat ini aplikasi pengolahan dokumen sudah dilengkapi dengan bantuan auto spelling correction.Aplikasi pengolahan dokumen (word processor) yang paling umum digunakan seperti Microsoft Office dan Open Office, sudah memiliki kemampuan untuk memeriksa ejaan atau mengkoreksi ejaan pada saat mengetik.

Aplikasi spell checker juga dapat ditemukan pada perangkat untuk mengetik email (email client), kamus elektronik dan mesin pencari (search engine). Namun aplikasi tersebut banyak dipakai untuk Bahasa Inggris. Beberapa penelitian sudah banyak dilakukan untuk membangun spell checker untuk bahasa Indonesia. Metode yang paling sering digunakan adalah Levensthein Distance.

Tim PKM juga sudah ikut membuat penelitian mengenai spelling correction dengan Levensthein Distance (Christanti, V. M., \& Naga, D. S., 2018), (Mawardi, V. C., Susanto, N., \& Naga, D. S., 2018). Metode ini merupakan salah satu metode yang baik dalam membangun spell checker memiliki akurasi sebesar $85 \%$ (Christanti, V. M., \& Naga, D. S., 2018).

Spell checker adalah salah satu perangkat lunak yang umum digunakan sebagai alat untuk melakukan proofreading pada naskah yang akan dicetak. Keberadaan spell dan grammar checker dapat meningkatkan kualitas dari naskah dimuat dalam bentuk dokumen elektronik.

Saat ini keberadaan spell dan grammar checker tersedia dalam segala bentuk bahasa, perbedaan bahasa tersebut menyebabkan dibutuhkannya spesifikasi yang khusus dalam membangun aplikasi tersebut (QasemiZadeh, B., Ilkhani, A., \& Ganjeii, A, 2006). Bahasa Jerman tentu saja berbeda dengan Bahasa Indonesia, Bahasa Inggris juga memiliki aturan dan kosa kata yang berbeda dengan Bahasa Indonesia.

Aplikasi spell checker juga dapat memiliki spesifikasi tertentu sesuai dengan tujuan dan kebutuhan masing-masing aplikasi. Spell checker dapat menjadi sistem yang terintegrasi dengan sistem lainnya seperti terintegrasi pada sistem pencarian diperpustakaan (Yulianto, M. M., Arifudin, R., \& Alamsyah, A., 2018). Sistem tersebut digunakan untuk menampilkan saran kata atau auto complete kata yang ditulis atau mencari kata yang sesuai walaupun terjadi kesalahan pengetikan.

Mitra membutuhkan aplikasi yang lebih sesuai dengan kebutuhan sekolah. Dimana proses pemeriksaan kata yang dilakukan pada saat mengetik akan mengganggu proses pengetikan sehingga diharapkan tersedia aplikasi yang dapat membantu memeriksa ejaan kata setelah mereka membuat soal. Perbedaan bentuk naskah yang dibuat seperti esai, pilihan ganda ataupun isian akan mempengaruhi proses aplikasi yang dibangun.

Dalam sebuah naskah soal, guru dapat memberikan soal kepada siswa dalam berbagai bentuk sehingga dalam satu file terdapat berbagai format bentuk soal pengetikan. Dibutuhkan aplikasi yang dapat membaca soal tersebut yang biasanya disimpan dalam bentuk word.

Pada umumnya guru mengetik soal tersebut dalam waktu yang singkat dikarenakan padatnya jadwal mengajar dan membuat soal. Setelah mengetik, pemeriksaan ulang akan dilakukan oleh guru yang bersangkutan atau guru lain. Ditemukanlah beberapa kesalahan ketik yang bisa saja membingungkan siswa. Atau membuat siswa tidak paham soal yang dimaksud.

Proses pemeriksaan ulang naskah soal diharapkan dapat dilakukan setelah seluruh naskah diketik, kemudian baru naskah tersebut diperiksa ulang oleh guru lain atau kepala sekolah. Sekolah SD Tiara Kasih ingin juga agar dapat meningkatkan pelayanan kepada siswa dengan cara memberikan soal yang cukup berkualitas dan terhindar dari kesalahaan pengejaan. Pemeriksa ejaan yang sudah tersedia belum dapat membantu guru-guru disekolah dalam memeriksa ulang naskah yang ditulis dalam Bahasa Indonesia.

Apabila ada aplikasi yang dapat digunakan untuk membantu memeriksa ulang naskah soal, kemudian memberikan tanda pada kata-kata yang kurang tepat ejaannya maka guru akan semakin mudah dalam memperbaiki kata-kata tersebut.Yang kemudian hasil perbaikan tetap dapat disimpan tanpa mengubah format dari soal tersebut.

Tujuan PKM ini adalah meningkatkan ketrampilan guru SD Tiara Kasih dalam menggunakan teknologi untuk membantu menyelesaikan masalah sekolah. Berdasarkan permasalahan pada sekolah SD Tiara Kasih, tim PKM bertujuan untuk menerapkan IPTEK yang

Teknologi Informasi dan Komunikasi 
merupakan hasil penelitian dari tim PKM. PKM ini akan mengimplementasikan sebuah aplikasi untuk mengkoreksi ejaan yang dapat disesuaikan dengan kebutuhan sekolah.

Aplikasi diberi nama Sistem Koreksi Ejaan Bahasa Indonesia (SKEBI) Dokumen Soal Ujian. Aplikasi akan dibuat agar dapat memeriksa dan memberi tanda terhadap kata-kata yang terdeteksi mengalami kesalahaan ejaan. Aplikasi akan dikembangkan agar tidak memberikan tanda dan merubah kata secara langsung pada saat pengetikan kata dilakukan.

Aplikasi akan dikembangkan agar dapat memeriksa satu dokumen secara utuh setelah guru selesai mengetikan naskah soal. Setelah naskah diperiksa, dokumen akan diberi tanda mana katakata yang kurang tepat. Dokumen dapat langsung diperbaiki secara otomatis atau diperbaiki secara manual.

Aplikasi akan dibuat berbasis web agar memudahkan para guru untuk menggunakan aplikasi tersebut. Dengan menggunakan aplikasi berbasis web guru tidak perlu meng-install atau menyiapkan apapun. Guru hanya tinggal membuka browser kemudian mengunggah naskah ke web dan mengunduhnya apabila sudah diperbaiki.

Tim PKM akan mengimplementasikan hasil penelitian sistem koreksi ejaan Bahasa Indonesia dengan metode Levensthein Distance dan Finite State Automata (Mawardi, V. C., Susanto, N., \& Naga, D. S., 2018) agar dapat digunakan untuk memeriksa naskah soal.

Levensthein Distance akan menghitung jarak antara kata sumber dengan kata target yang lain. Jarak yang akan dihitung menggambarkan kesalahan substitution, insertion, deletion, transposition dan split word (Barari \& QasemiZadeh, 2005). Hasil perhitungan itu dapat membantu untuk menampilkan daftar kata yang menjadi saran kata untuk memperbaiki kata tersebut.

Pada spelling correction yang dirancang, Finite State Automata digunakan untuk merepresentasikan kamus dan juga input berupa kesalahan kata untuk mempermudah penghitungan levenshtein distance (Lazarov, M., 2006)).

Aplikasi dibuat dengan dua macam bentuk, aplikasi dapat langsung memperbaiki kata yang salah eja secara otomatis dan aplikasi dapat memperbaiki kata yang salah eja secara manual. SKEBI Dokumen diharapkan dapat menerima input berupa soal ujian dalam bentuk pilihan ganda, esai atau isian.

Setelah itu guru dapat mengarahkan mouse ke setiap kata yang bertanda dan pada saat dipilih akan muncul daftar kata-kata yang menjadi saran perbaikan. Setelah muncul, maka guru dapat memilih kata yang menjadi saran perbaikan. Apabila guru tidak mau memilih maka guru bisa melakukan proses perbaikan secara otomatis.

Input dari soal tersebut dapat dideteksi apakah ada kesalahan pengetikan atau tidak. Kata yang dianggap salah akan mendapatkan tanda merah. Kata yang mendapatkan tanda merah dapat diklik dan dilihat kata-kata yang menjadi saran perbaikan.

Setelah diperbaiki, maka kata tersebut akan berubah sesuai kata yang dipilih. Atau aplikasi dapat juga memperbaiki semua secara otomatis namun dengan konsekuensi dapat saja terjadi kata yang menjadi saran perbaikan kurang tepat atau tidak sesuai dengan maksud dari soal tersebut.

Aplikasi SKEBI Dokumen ini dikembangkan untuk dapat menerima dokumen dalam bentuk docx, txt atau pdf sehingga guru dapat mengupload dalam beberapa bentuk file. Aplikasi ini juga diimplementasikan agar dapat disesuaikan dengan kebutuhan guru. Sehingga tampilan aplikasi ini disesuaikan dan ditampilkan dalam bentuk yang sesuai dengan sekolah tersebut.

\section{METODE}

Tim PKM akan membuat aplikasi Sistem Koreksi Ejaan Bahasa Indonesia (SKEBI) sesuai kebutuhan sekolah untuk memeriksa naskah. Dalam membuat aplikasi ini dibutuhkan kepakaran dalam bidang Information Retrieval dan Natural Language Processing. Perancangan alur dan pembuatan antar muka yang sesuai dengan sekolah membutuhkan bidang Rekayasa Perangkat Lunak agar dihasilkan aplikasi yang user friendly dan mudah digunakan.

Tim PKM ini merupakan tim yang pakar didalam bidangnya. Tim PKM terdiri dari 3 orang dosen yang memiliki kepakaran dalam bidang Information Retrieval bidang web, jaringan dan distributed application dan rekayasa perangkat lunak serta testing implementasi. Mahasiswa FTI 1

Teknologi Informasi dan Komunikasi 
orang yang membantu membuat dokumentasi dan asisten PKM bertugas untuk membantu membuat program.

SKEBI Dokumen merupakan hasil penelitian yang sudah dilakukan pada hibah internal tahun 2018 dengan judul "Sistem pengkoreksian ejaan otomatis pada Bahasa Indonesia". Pada penelitian ini hanya dicoba apakah aplikasi dapat mengenali kata-kata salah eja pada dokumen berupa .txt.

PKM ini dilakukan dengan menggunakan metode pengembangan program komputer yaitu System Development Life Cycle (SDLC). Metode SDLC terdiri dari lima tahap yang dapat dilihat pada gambar 1. Diantara tahapan tersebut, dapat terjadi kembali lagi ke tahapan sebelumnya apabila tahapan tersebut sudah dilewati.

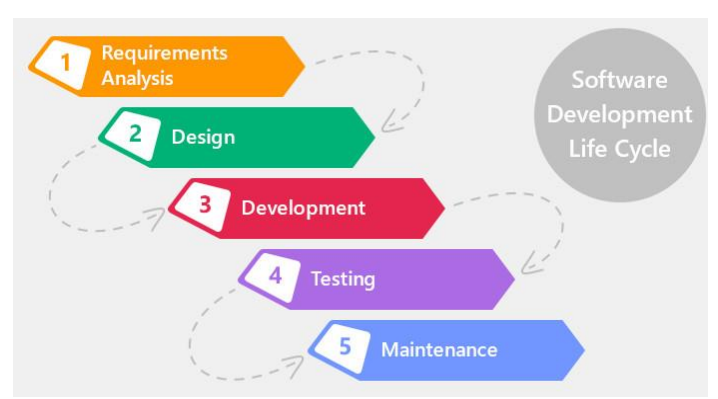

Gambar 1. Tahapan SDLC

Lima tahapan SDLC sesuai (Kendall \& Kendall, 2006) tersebut terdiri dari analisis kebutuhan dilakukan dengan melalui wawancara kepada mitra, tahap selanjutnya merancang bentuk aplikasi sesuai masukan dari sekolah, membuat program SKEBI berdasarkan hasil penelitian yang sudah dilakukan. Setelah hasil aplikasi disesuaikan dengan kebutuhan sekolah tahapan selanjutnya adalah melakukan implementasi dan uji coba oleh guru. Demi keberlangsungan aplikasi ini maka tahap terakhir adalah pemeliharaan aplikasi yang dilakukan oleh tim PKM.

Pada pengabdian ini tim PKM akan membuat buku panduan penggunaan aplikasi SKEBI Dokumen sebagai materi yang akan diberikan kepada guru. Dengan panduan ini guru dapat mempelajari dan menggunakan dengan mudah.

Produk yang dihasilkan haruslah sesuai dengan kebutuhan mitra. Oleh karena itu dalam proses pelaksanaan pengabdian, tim PKM membutuhkan masukan, saran dan input mengenai aplikasi yang sudah tersedia. Saran tersebut akan menjadi masukan bagi tim PKM untuk menyesuaikan dan memperbaiki produk yang sedang dirancang.

PKM ini dilaksanakan mulai bulan JanuariOktober 2019. Pembuatan program dilakukan pada bulan Januari-Agustus 2019 dan penyerahan produk dilakukan pada tanggal 3 Agustus 2019 di sekolah Tiara Kasih. Pada tabel 1 dapat dilihat jadwal pelaksanaan PKM. Tim PKM harus menyesuaikan waktu dengan kegiatan sekolah agar tidak mengganggu kegiatan belajar mengajar di sekolah.

Tabel 1. Jadwal kegiatan PKM

\begin{tabular}{|c|c|c|c|}
\hline No & Kegiatan & Keterangan & Jadwal \\
\hline 1 & $\begin{array}{l}\text { Pengumpulan } \\
\text { data materi }\end{array}$ & $\begin{array}{l}\text { Pengumpulan masukan, } \\
\text { saran atau informasi } \\
\text { mengenai kekurangan } \\
\text { atau kelebihan program } \\
\text { yang dirancang. } \\
\text { Masukan atau saran } \\
\text { dapat diberikan secara } \\
\text { lisan atau melalui email }\end{array}$ & Januari 2019 \\
\hline 2 & $\begin{array}{l}\text { Pembuatan } \\
\text { aplikasi }\end{array}$ & $\begin{array}{l}\text { Tim menerapkan } \\
\text { IPTEK hasil penelitian } \\
\text { dalam bentuk program } \\
\text { yang dapat digunakan } \\
\text { oleh sekolah }\end{array}$ & $\begin{array}{l}\text { Januari- } \\
\text { Agustus } \\
2019\end{array}$ \\
\hline 3 & $\begin{array}{l}\text { Penyerahan } \\
\text { produk dan } \\
\text { manual }\end{array}$ & $\begin{array}{l}\text { Tim menyerahkan } \\
\text { produk versi } 1 \text { dan } \\
\text { manual penggunaan } \\
\text { produk }\end{array}$ & $\begin{array}{l}3 \text { Agustus } \\
2019\end{array}$ \\
\hline 4 & $\begin{array}{l}\text { Pengujian dan } \\
\text { implementasi }\end{array}$ & $\begin{array}{l}\text { Guru menguji seluruh } \\
\text { aplikasi. } \\
\text { Setelah selesai, produk } \\
\text { akan } \\
\text { diimplementasikan } \\
\text { dengan memberikan } \\
\text { domain. }\end{array}$ & $\begin{array}{l}\text { September } \\
2019\end{array}$ \\
\hline 5 & $\begin{array}{l}\text { Pembuatan } \\
\text { laporan }\end{array}$ & $\begin{array}{l}\text { Tim PKM membuat } \\
\text { laporan hasil evaluasi } \\
\text { program PKM }\end{array}$ & $\begin{array}{l}\text { Oktober } \\
2019\end{array}$ \\
\hline
\end{tabular}

Setelah produk diserahkan maka sekolah dapat memberikan masukan mengenai aplikasi yang lebih sesuai dengan kebutuhan guru. Setelah itu dilakukan penyesuaian dan perbaikan program agar dapat menghasilkan aplikasi yang lebih baik. Dimana aplikasi terus disesuaikan dalam 2 bulan berikutnya untuk menyempurnakan seluruh aplikasi.

Teknologi Informasi dan Komunikasi 
Pengabdian ini memiliki target utama yaitu hasil aplikasi yang dapat berguna dan digunakan seterusnya untuk membantu pengelolan SKEBI Dokumen Soal Ujian dengan metode Levensthein Distance berbasis web agar sekolah tidak perlu menginstalnya dalam setiap komputer. Penggunaan berbasis web ini dapat memudahkan guru untuk membuka dan menggunakannya dimana pun berada dan dengan spesifikasi komputer apapun.

\section{HASIL DAN PEMBAHASAN}

\section{Hasil Pengembangan Aplikasi SKEBI}

Pada PKM ini, dikembangkan sebuah aplikasi spelling correction untuk memeriksa pengetikan ejaan dalam bahasa Indonesia. Aplikasi ini dikembangkan secara khusus untuk dapat membaca, memeriksa dan menyimpan kembali file berupa naskah soal untuk siswa sekolah dasar.

Aplikasi ini diberi nama SKEBI Dokumen Soal Ujian yang dapat diakses melalui website dengan tampilan yang dapat dilihat pada gambar 2 .

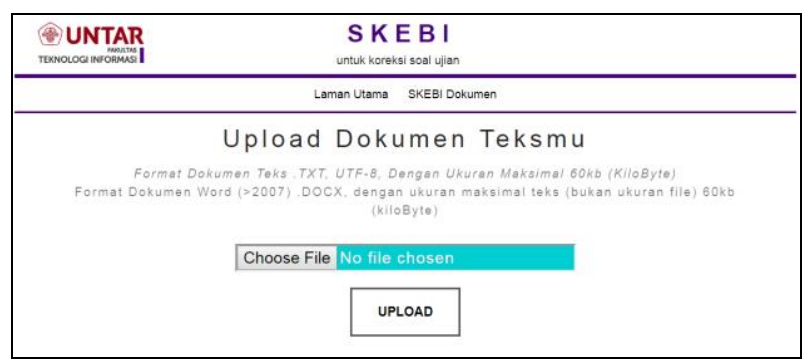

Gambar 2 Tampilan Utama SKEBI Soal Ujian

Penggunaan SKEBI Dokumen Soal Ujian dimulai dengan mengunggah file soal terlebih dahulu. Guru menekan tombol Browse, lalu memilih file yang akan diunggah. Contoh soal (berupa file word dengan ekstensi docx) yang akan diperiksa dapat dilihat pada Gambar 3. Soal terdiri atas 2 soal pilihan ganda, 3 soal isian, dan 2 soal esai. Kata yang dibuat salah adalah 1) "Resendi" (soal nomor 2 pilihan A), 2) "Persaman" (soal nomor 4) dan 3) "Hubunggan" (soal nomor 7).

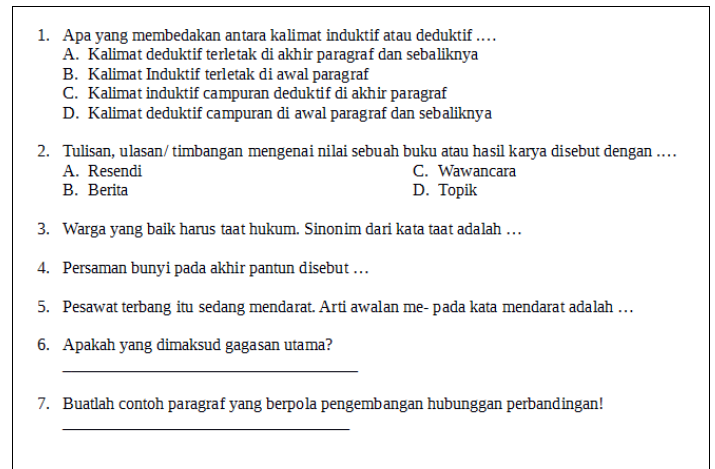

Gambar 3 Contoh soal ujian dalam bentuk file word

Tampilan setelah memilih file dapat dilihat pada Gambar 4. Kemudian guru menekan tombol Upload untuk memulai proses pemeriksaan ejaan.

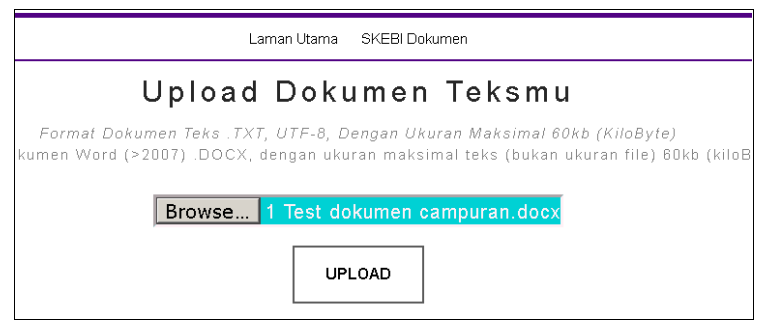

Gambar 4 Tampilan Setelah Pilih File Word

Setelah selesai, sistem akan menampilkan isi file. Apabila ada kata yang dianggap salah, sistem akan memberikan tanda merah pada kata tersebut. Keseluruhan hasil pemeriksaan ejaan dapat dilihat pada Gambar 5 sampai Gambar 8. Pada Gambar 4 terlihat ada kata "Resendi" yang ditandai salah oleh sistem.

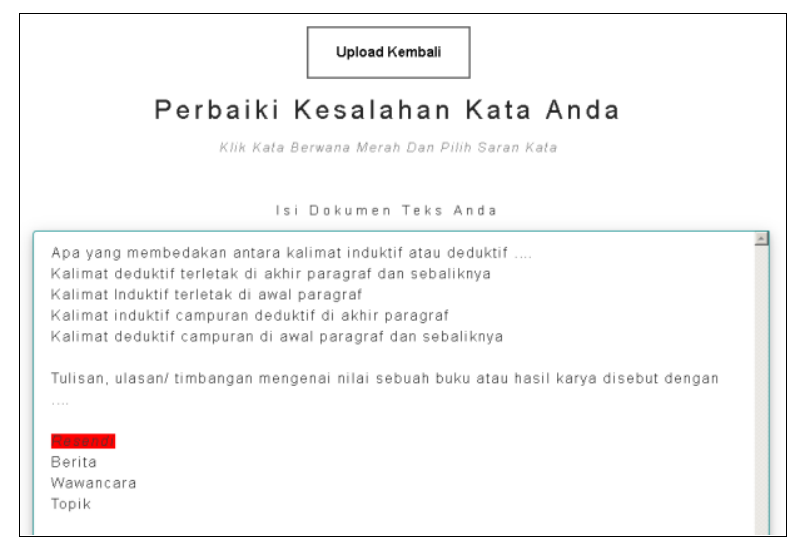

Gambar 5 Tampilan Setelah Pemeriksaan Ejaan

Teknologi Informasi dan Komunikasi 
Arahkan dan pilih kata "Resendi" untuk melihat pilihan kata untuk memperbaiki kata tersebut. Pilihan kata dapat dilihat pada Gambar 6.

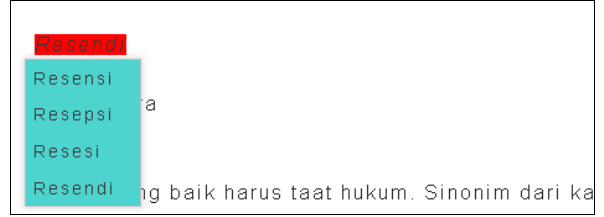

Gambar 6 Pilihan Koreksi untuk Kata "Resendi"

Arahkan kursor ke kata "Resensi" dan tekan kata tersebut untuk memperbaiki kata "Resendi". Hasil perbaikan dapat dilihat pada Gambar 7.

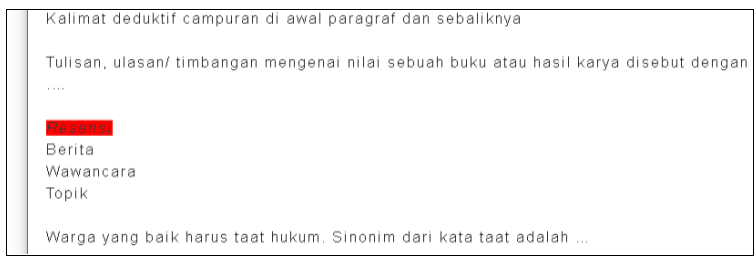

Gambar 7 Hasil Setelah Koreksi Kata "Resendi" Menjadi "Resensi"

Lalu geser ke bawah untuk melihat tampilan seperti Gambar 8. Tampak masih ada beberapa kata yang ditandai salah oleh sistem.

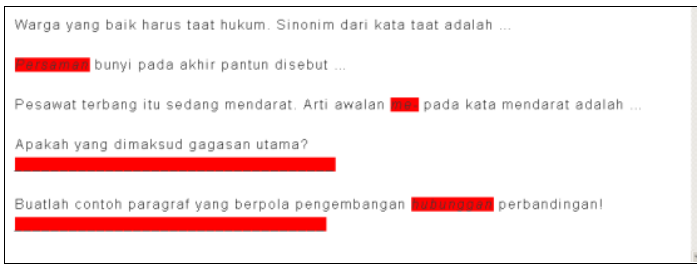

Gambar 8 Lanjutan Hasil Pemeriksaan Ejaan

Apabila semua kata telah diperiksa dan teks telah dianggap benar, guru dapat menekan tombol Koreksi Manual untuk mengakhiri proses perbaikan manual. Pengguna tidak lagi dapat mengubah kata setelah memilih tombol tersebut.

Tekan tombol download untuk mengunduh file word. Ada browser yang langsung mengunduh file, ada yang meminta konfirmasi dari user. Salah satu contoh pesan konfirmasi dari browser dapat dilihat pada Gambar 9.

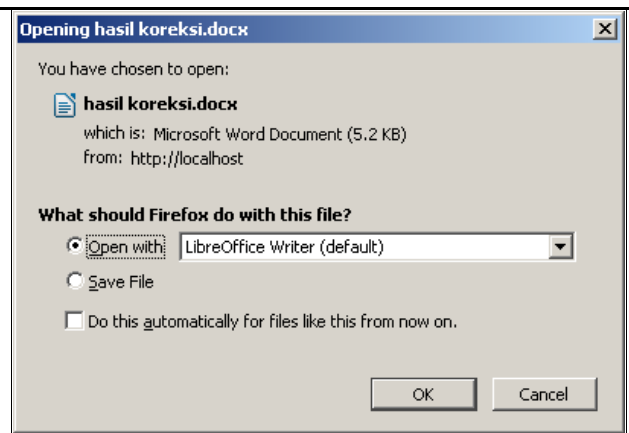

Gambar 9 Contoh Pesan yang Ditampilkan Setelah Pilih Download

Gambar 10 memperlihatkan isi file word yang diunduh setelah melalui proses pemeriksaan oleh sistem dan perbaikan oleh guru.

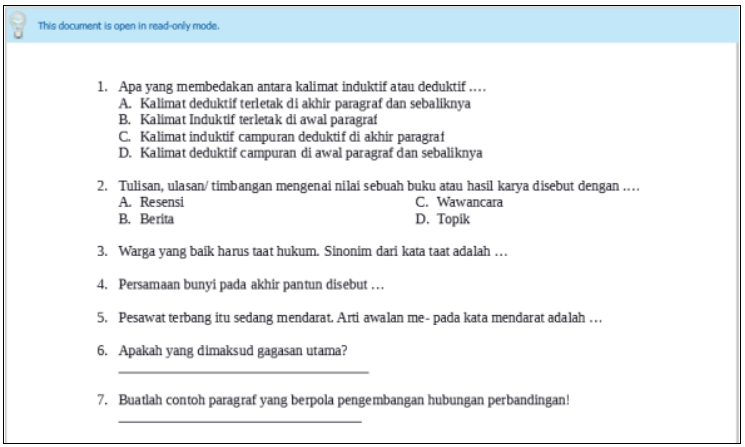

Gambar 10 Isi File Word Soal Setelah Koreksi

\section{Pembahasan Hasil PKM}

Berdasarkan tujuan awal PKM, bentuk program dari PKM ini adalah membuat program aplikasi SKEBI Dokumen Soal Ujian dengan menerapkan IPTEK hasil penelitian yang sudah dilakukan oleh tim peneliti PKM. Sehingga evaluasi PKM dilakukan dalam bentuk obeservasi guru-guru pada saat mencoba menggunakan aplikasi ini.

Tim PKM telah menyerahkan aplikasi SKEBI Dokumen ke SD Tiara Kasih. Penyerahan aplikasi produk diberikan dalam bentuk buku panduan dan usb flash disk kepada guru-guru SD Tiara Kasih. Seluruh guru berjumlah 34 orang. Penyerahan diwakilkan oleh kepala sekolah. Foto penyerahan dapat dilihat pada gambar 11 .

Evaluasi PKM dilakukan dengan observasi hasil pengujian aplikasi yang dilakukan oleh para guru pada saat menggunakan aplikasi tersebut. Apakah dengan menggunakan aplikasi ini para guru dapat dengan mudah mendeteksi kesalahan eja yang 
ada pada soal. Saat ini proses evaluasi belum dilakukan dalam bentuk kuesioner karena guru-guru masih terus berlatih menggunakan aplikasi ini.

Berdasarkan hasil obeservasi beberapa masukan dari guru adalah terbatasnya aplikasi yang hanya dapat memproses tipe soal pilihan ganda, isian, dan esai. Adapun permintaan agar aplikasi tersedia secara offline agar dapat digunakan tanpa koneksi internet.

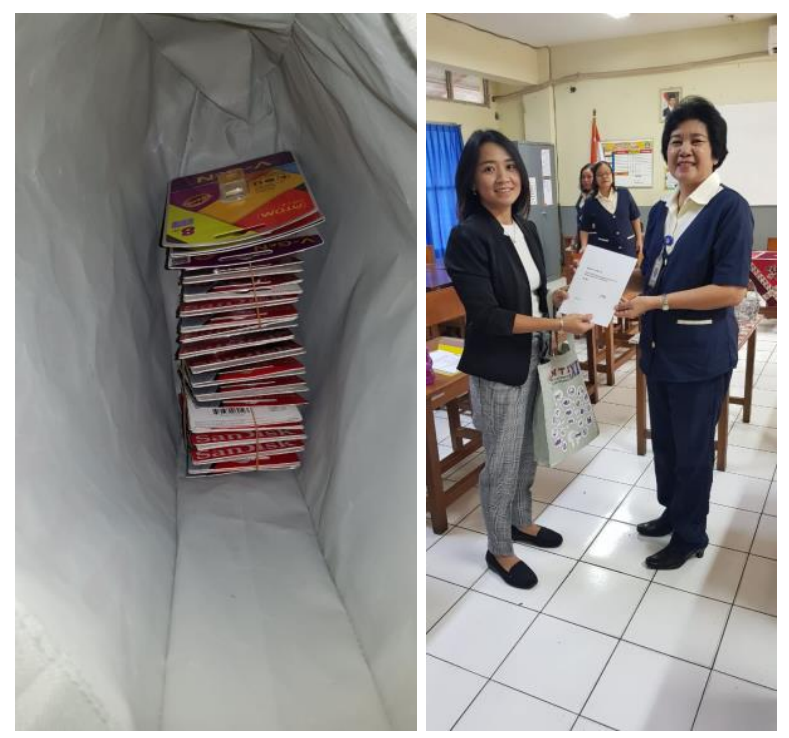

Gambar 11 Penyerahan USB dan buku panduan kepada guru SD Tiara Kasih

SKEBI dokumen hanya menampilkan isi file dalam bentuk teks biasa pada menu html sehingga tidak terlihat formatnya namun pada saat disimpan ke dalam file word soal akan kembali dalam bentuk format asal seperti pilihan ganda, isian dan esai. SKEBI hanya menampilkan teks saja. Belum dapat mengolah teks yang terdapat dalam footer, header atau lainnya dan belum dapat mengolah soal dalam bentuk rumus dan lainnya yang umumnya digunakan untuk tingkat SMP dan SMA.

\section{KESIMPULAN}

PKM ini telah mengembangkan sebuah aplikasi yang berguna bagi guru-guru untuk memudahkan pekerjaan mereka dalam memeriksa naskah soal agar bebas dari kesalahan pengetikan. Penggunaan SKEBI Dokumen Soal
Ujian ini dapat meningkatkan kualitas soal yang dibuat oleh guru-guru SD. Tiara Kasih.

Guru-guru sangat menerima aplikasi ini dan berpendapat bahwa aplikasi ini dapat mempermudah pekerjaan mereka dalam mengevaluasi naskah soal yang sudah dibuat. Penggunaan aplikasi ini masih terus diuji oleh guruguru sekolah agar dapat menerima masukan dari guru-guru apakah kata yang dikenali sebagai kata yang salah sudah tepat atau apakah masih ada kata yang tidak salah namun dikenali salah.

Hasil aplikasi ini masih harus terus dikembangkan mengingat banyaknya perbendaharaan kata yang digunakan dalam membuat soal. Hasil uji coba oleh guru-guru tersebut akan disimpan dan digunakan sebagai masukan agar aplikasi ini dapat diperbaharui secara berkala.

Proses evaluasi selanjutnya akan dilakukan setelah seluruh guru mendapatkan pelatihan penggunaan aplikasi sehingga dapat dilakukan evaluasi hasil pelatihan sebelum dan sesudah menggunakan aplikasi.

\section{UCAPAN TERIMAKASIH}

Terima kasih kepada Direktorat Penelitian dan Pengabdian Masyarakat Untar yang telah mendanai pengabdian ini. Terima kasih pula kepada guru-guru SD. Tiara Kasih yang sudah memberikan waktu dan kesempatan kepada tim PKM untuk kerjasamanya.

\section{REFERENSI}

Barari, L., \& QasemiZadeh, B. (2005). CloniZER spell checker adaptive language independent spell checker. In AIML 2005 Conference CICC, Cairo, Egypt (pp. 19-21).

Christanti, V. M., \& Naga, D. S. (2018). Fast and Accurate Spelling Correction Using Trie and Damerau-levenshtein Distance Bigram. TELKOMNIKA, 16(2), 827-833.

Kendall, K. E., \& Kendall, J. E. (2010). Systems analysis and design. Prentice Hall Press.

Lazarov, M. (2006). Finite-state methods for spelling correction. Unpublished BA thesis. 
Mawardi, V. C., Susanto, N., \& Naga, D. S. (2018). Spelling Correction for Text Documents in Bahasa Indonesia Using Finite State Automata and Levinshtein Distance Method. In MATEC Web of Conferences (Vol. 164, p. 01047). EDP Sciences.

Pirinen, T. (2014). Weighted Finite-State Methods for Spell-Checking and Correction.

QasemiZadeh, B., Ilkhani, A., \& Ganjeii, A. (2006, June). Adaptive language independent spell checking using intelligent traverse on a tree. In 2006 IEEE Conference on Cybernetics and Intelligent Systems (pp. 1-6). IEEE.
Sani, R. A. (2013). Inovasi pembelajaran. Jakarta: Bumi Aksara.

Tiara Kasih. (2018). Histori Tiara Kasih. Diakses dari http://sekolahtiarakasih.sch.id/.

Yulianto, M. M., Arifudin, R., \& Alamsyah, A. (2018). Autocomplete and Spell Checking Levenshtein Distance Algorithm To Getting Text Suggest Error Data Searching In Library. Scientific

Informatics, 5(1), 75.

\section{Journal}

of 